\title{
Development of Hypercontent Module using Jonnuro Model Learning Desain for Candidates Master Guide
}

\author{
Jhoni Lagun Siang, Nurdin Ibrahim, Robinson Situmorang
}

\begin{abstract}
The aim of this study is to produce a hyper content teaching material for prospective master quide in the adventist church. Which can be used for independent learning. This study uses a combination Derek Rowntree's model and borg and gall models. The product testing phase begin with testing material expert, media experts, and learning disign expert. Then the product was tested to a number of master quide candiates, namely 3 people for individual evaluation, 8 people for small group evaluation and 20 people for large group evaluation. The result of the study showed the value of material expert, linguistic expert, media expert and learning design expert was very good. Judging from the readability test conducted by researchers using fog index, the module material is included in thecategory easy. According to the material expert, the hypercontent module, in terms of content feasibility, the feasibility of the feasibility of presentation according to material experts has been very good.According to linguists, the hypercontent module, in terms of the feasibility of language feasibility it has been very good. According to the learning design, the module is hypercontent, in terms of learning design is very good. Whereas according to expert media and graphic design, all module components are complete, the module size is appropriate and the visual message design principle is very good. According to the candidate master guide this module, in terms of method, evaluation, module size, language, sentence structure, layout, typography, illustrations and colors in the module have been very good.
\end{abstract}

Index Terms: Research and Development, Hypercontent, Learning Material, jonnuro Model

\section{INTRODUCTION}

Entering the Industrial Revolution era 4.0 which is the application of cyber-physical systems in various fields for automation and data exchange, which brings a variety of accelerated extraordinary progress to increase effectiveness and efficiency in various fields that we are familiar with the growth of smart factories, smart cities, smart learning, and digitizing in various fields. This situation requires

Revised Manuscript Received on September 22, 2019.

Jhoni Lagun Siang, Post Graduated Departmen of Educational Technology Universitas Negeri Jakarta, Rawamangun muka street Rawamangun Pulogadung, East Jakarta 13220, Indonesia, and Lecturer at Universitas Bumi Hijrah Maluku Utara, Sofifi, North Molucas Indonesia 97852,.jhonilagun_tp17s3@mahasiswa.unj.ac.id,

Nurdin Ibrahim, Profesor at Universitas Negeri Jakarta, Rawamangun muka street, Rawamangun Pulogadung, East Jakarta 13220 nurdin1349@yahoo.com.

Robinson Situmorang, Lecturer at Universitas Negeri Jakarta, Rawamangun muka street, Rawamangun Pulogadung, East Jakarta 1322, rbionsonsitumorang@gmail.com professionals in the field of educational technology to play a lot of roles both directly building instructional design for smart learning, as well as supporting components.

The rapid development of digital technology has influenced developments and changes in the world of education and teaching, with various terms, such as distance learning, virtual education, internet-basedweb-based education,education, and education through computer-mediated communication.

The development of science and technology allows all parties to obtain information abundantly, quickly and easily from various sources and places in the world. Thus, students need to have the ability to obtain, choose and manage information to survive in an ever-changing, uncertain and competitive situation. To do this requires the ability to think systematically, logically, creatively, rationally and the desire to cooperate. This way of thinking can be developed through learning usinglearning materials hypercontent, becauselearning materials hypercontent have strong and clear links between concepts taught with technological and information development.

The process that occurs in education leads to the learning process. "Learning is enduring change in behavior, or in the capacity to behave in a given fashion, which results from practice or other forms of experience" (Schunk, 2012). Learning is a lasting change in behavior, or in the capacity to behave in a certain way, the result of practice or other forms of experience. Referring to Anurrahman (2010), learning is a process carried out by individuals to obtain a change in new behavior as a whole, as a result of the experience itself in interaction with the environment (2).

Learning is a learning activity both with the guidance of learners and with their own full efforts. The presence of other people including learners is intended to make learning more smoothly, easier and more successful (3). In learning activities required interaction between learners and learning resources, so that in these activities obtained maximum results, the level of interaction must be high. Therefore, interactions need to be developed systematically. Likewise learning resources need to be developed and managed systematically, well and functionally.

The progress of science and technology has an impact on the world of education. Therefore, the education and learning paradigm also undergoes a shift and transformation (4). The shift 
is (1) focusing on developing individual potential holistically, (2) learning does not only occur in the classroom but the environment is also an effective source of learning, (3) the communication model of educators and students is more interactive and democratic (4) assessment of learning is not only results oriented but also process, (5) and the diversity of characteristics of students in learning requires sensitivity of educators. This paradigm shift has implications for the nature of the learning process, learning resources, the role of educators, students, and learning evaluation systems.

The maximum use of learning resources can improve learning achievement of students (students). This is in line with research that compares student learning achievement using learning resources and students who do not use learning resources. The study found that there were significant differences between students who had the intensity of the use of high learning resources with students who had the intensity of the use of low learning resources regarding learning achievement (5).

Today the learning process can take place without having to study in the classroom because of the development of learning resources, especially information and communication technology that is very fast. The learning process is no longer dependent on the teacher as a source of learning. But it can take place anytime and anywhere. The learning process is no longer in the form of verbal communication between learners of students and teachers. Thus students can learn anything according to their interests and learning styles. But in reality diverse learning resources generally have not been fully utilized (Percival, 1993).

Therefore, the use of learning resources is an effort to solve learning problems. In the context of educational technology, learning resources are components of the learning system that need to be considered, some are designed in advance or use existing ones, and in combination in a complete learning system to implement a learning process that is purposeful and controlled. These learning resources are identified as messages, people, materials, tools, techniques, and settings (Seels \& Richey, 1994). Learning technology also develops by taking four main characteristics, namely; (1) applying a system approach, (2) using the widest possible learning resources, (3) aimed at improving the quality of human learning, and (4) orienting towards individual learning activities (8). Abdalraheem and Al-Rabane (2006) also found that the use of textbooks in classrooms was still very dominant (Abdelraheem \& Al-Rabane, 2006).

It should be realized that learning is a system, in which there are a number of components that are interconnected with each other in order to achieve the goal. Learning is a system so the success of learning is largely determined by the extent to which the effectiveness of each component interacts.

In the learning process, the teacher cannot work alone to be able to make students learn, but the teacher must also be assisted by quality learning resources and learning media. According to Dewanto (2015), formulated learning can increase the knowledge and skills of competencies needed (10).

To support teaching, teachers need media that can be used in teaching. Like text books, CDs / DVDs, picture cards, posters, internet and so on. Textbooks like world windows, are a tool for teachers and students to understand what is needed.

The results of research conducted by Pannen, et al (2003) in many universities in Indonesia found that the use of learning materials and textbooks in learning was very dominant compared to other learning resources such as libraries, laboratories, field studies, slides and internet, computers and others. However, the use of computers in learning shows a significant increase at this time (Pannen, Pribadi \& Kusnadi, 2003).

The tendency to use learning resources in the form of textbooks or learning books because of the view that other learning resources are additional (as a supplement) in learning. This reinforces the assumption that the use of learning resources is not an integral part of learning, but helps the learning process.

During this time, in addition to books as a source of reliable learning, educators in their class are also the main actors. Educative functions are primarily concerned with presenting, explaining, analyzing and accounting for the body of material that must be learned. Learners are still dominantly passive (12). This reinforces the idea that other learning resources are only additional means of learning.

Ideally, learning resources must be an integral part of the learning process, because their use will be able to create a clearer learning experience and can facilitate interactions between students and teachers and students with other students. The use of learning resources will also enrich students' learning experiences.

In addition, the use of learning resources is able to change the culture of learning from passive students to students who actively discuss and seek knowledge from various learning resources available, while teaching staff act as facilitators who are both involved in the learning process with students (12). In the learning process, the more learning resources used, the learning activities will be more complete, and the picture of the subject being studied will be more clear and meaningful. The problem now is how teachers design to use learning resources. At present, learning resources that can be used to meet learning needs vary greatly. This source of learning is not only in the form of printed material such as textbooks, but students can benefit from other learning resources such as educational radio, television, teleconferencing, e-mail, interactive video, satellite communication, multimedia technology to enhance interaction and provide understanding to students. This is in agreement with Mcisaac and Gunawardena (1996) which states that learning resources are not only in the form of printed materials such as textbooks but learners can take advantage of other learning resources such as radio education, television, computer conferencing,

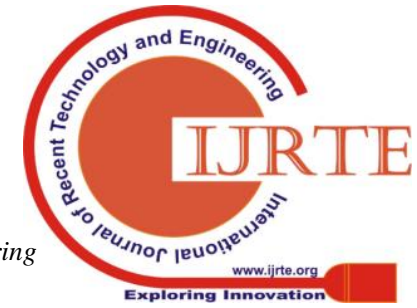


e-mail, interactive video, communication satellite and multimedia computer technology to enhance interaction and provide mutual feedback with learners (Mcisaac, Gunawardena, 1996).

According to Subradi (2015), the tendency to use different learning resources in educational units is influenced by two main factors, internal factors and external factors. Internal factors are the dominant factors that influence the awareness, desires, interests, abilities and comfort of the user himself. External factors that influence the availability of diverse learning, the number of learning resources, accessibility to learning resources, space, human resources, traditions and regulations applied in educational institutions (14).

The results of Lilawati (2017) study, the results showed that the use of learning resources in the learning process at SDIT Hamas Stabat in the form of messages included quite good categories with a percentage of $70 \%$, human learning resources including quite good categories with a percentage of $74 \%$, material learning resources including categories quite good with a percentage of $66 \%$, learning resources methods included in the less category with a percentage of $49 \%$, learning resources tools included in the fairly good category with a percentage of $74 \%$, environmental learning resources including a fairly good category with a percentage of $69 \%$. Of the most dominant learning resources used are human learning resources and methods. Efforts to use learning resources in the learning process at SDIT Hamas Stabat include a fairly good category with a percentage of $71 \%$ (15).

In line with the development of science and technology, there are more learning resources, allowing people to learn independently. The transformation of the industrial era into the information age requires changes in various fields, including education. In the information age, students face a lot of information as well as more than before. This information is disseminated through various print and electronic media, from simple technology to advanced technologies such as the internet, and so on.

Each learning resource has a different role, depending on how learning resources are used. In learning students, they not only interact with the teacher as a source, but also interact with all learning resources that allow it to be used to achieve the desired results.

Thecurriculum Master Guide (MG) is a youth department leadership program in the Seventh-day Adventist Church to train youth leadership. The master guide is an expert, advisor, promoter for the adventurers and pathfinder. This concept uses acurriculum master guide as a foundation for junior youth service leadership and helps maintain youth leaders, up-to-date, and focuses on why we are in this regard. But unfortunately the Seventh-day Adventist Church's ministry only provides curricula, while learning materials are not provided.

The results of the interview to the Instructor (Master Guide) conducted at the 7th Day Adventist Church on February 17, 2019 indicate the existence of problems that must be as resolutely addressed. The problems encountered were: Is the material for theclass master guide provided by the youth department? "We were only given the curriculum in English and not complete, to teach we had to search for material that was related to the demands of the curriculum so it was very difficult in teaching" " (Marpaung, 2019).

The researcher also interviewed the prospective master guide interview results showed that: "Not at home learning because the method used by the instructor is only a lecture method, we have difficulty working on the assignments given and the availability of textbooks, learning materials are not available on the Internet" (17).

The unavailability of learning materials also influences the creativity of prospective master guides, for example, one of the demands of the class is telling children stories. Most prospective master guides find it difficult to adapt to the "child's world" they do not understand the concepts of storytelling so the message delivered is not the same as the actual purpose. Likewise with the demands of other classes such as preaching, and being conductors, prospective master guides find it difficult to practice the demands of the class. One reason is the unavailability of learning materials for them.

From the various problems above, the essence of educational technology is a scientific discipline for solving learning problems based on a set of principles and using various approaches, such as those proposed by Januszewski and Molenda (2008) that are in accordance with the AECT 2008 definition: "Educational technology is the study and ethical practice of facilitating learning and improving performance by creating, using, and managing appropriate technological processes and resources (Januszewski \& Molenda, 2008). That is, educational technology is the study and ethical practice in an effort to facilitate learning and improve performance by creating, using and managing the processes and appropriate technological resources.

The philosophy is the realization of various patterns of education and learning by developing and utilizing a variety of various learning resources and according to conditions and needs. Researchers feel the need to solve the right problem, especially providing learning resources specifically made for them.

By paying attention to the principle of learning, one type of learning material that supports learning principles is a module.

\section{LITERATURE REVIEW}

\section{A. Modules}

Knowledge obtained by students not only comes from the delivery of teachers, but also obtained from various supporting learning resources. Learning resources according to the Association for Educational Communication and Technology, AECT in Sitepu i.e. various or all sources in the form of data, people and certain forms that students can use in learning, both separately and in combination that can facilitate students in 
achieving learning goals (Sitepu, 2014).

The source of learning is not only limited to materials and tools used in the learning process, but also costs and facilities. Learning resources are made intentionally or developed, and some are used because they are available, such as museums, beaches, markets, etc. Briefly learning resources cover what can be used to help everyone to learn and display their competencies (20).

21 st century learning is learning that no longer emphasizes the teacher as a learning center. The 21st century learning system is a learning transition where the curriculum developed at this time requires schools to change the learning(-centered learningteacher-centered learning) approachinto aapproach student-centered learning. Through this learning approach, it is expected to create independent students. One of the independent learning materials and supports students' independence in learning is the module.

The module is a learning material that is structured with the aim that students can learn independently without or with limited guidance from the instructor. Modules as self-learning materials can be defined as a learning process related to certain discussion units that are arranged systematically, operationally and directed to be used by learners along with guidelines for their use for learners (Ibrahim, 2010). Ibrahim (2010), interpreting the module as a component of independent learning material that includes all learner needs including learning goals, guidelines for use, material descriptions, learning progress, learning evaluation, improvement programs and follow-up (21).

Smaldino, Lowther and Russell (2012) define learning modules as learning that are packaged into one whole unit that is designed to be used alone or a group of learning without teacher's presence (Smaldino, Lowther \& Russell, 2012). Thus it can be concluded that the module is one form of learning material that is packaged intact and systematically that contains a set of planned learning experiences and is designed to help students master specific learning goals. Modules can be used as one of the learning materials to facilitate independent or conventional learning.

\section{B. Independent Learning}

The independent learning model is developed so that students are able to manage their own learning process. Ibrahim (2010) explains that in independent learning each student must be able to learn on his own initiative, either with or without others (21)Learning initiatives are defined as students can analyze learning needs, formulate learning goals, identify learning resources, choose learning strategies that are in accordance with themselves and able to evaluate their own learning outcomes.

Meanwhile, Kesten quoted by Ibrahim (2010), defines independent learning as a form of learning where students can make important decisions according to their own learning needs. So that it can be concluded that in independent learning students have the responsibility to organize their own learning activities (21).

Yamin (2007) defines independent learning as a learning activity carried out by students freely determining their learning goals, the direction of learning, using learning resources chosen, making academic decisions and carrying out activities to achieve their learning goals (23).

Each student has a level of learning independence that is not the same or different. Schunk \& Ertmer in Rahayu and Widodo (2017) states that learning independence refers to a person's thoughts, feelings, and actions that are planned and adjusted systematically according to their needs so that it affects a person's learning and motivation (Rahayu \& Widodo, 2017). In other words students who have a low level of learning independence tend to have low learning achievement in schools and vice versa, students who have a high level of independence tend to have good learning achievements at school.

Hargis (2000), argues that there are 4 benefits related to students' independence in learning, namely:

1. Students with high independence tend to learn better than controlled learning.

2. Students with high independence are able to monitor, evaluate, or manage their learning effectively.

3. Independent learning can reduce the learning time needed to complete the lesson.

4. Students with high independence are able to manage their learning and time efficiently (25).

\section{Learning Development}

According to Smith and Ragan, in Newby, Stepich, Lehman, Russell, and Leftwich (2011), "Instructional design is a systematic and reflective process of translating principles of learning and instructional materials, activities, information, resources, and evaluation" (Newby et al, 2011). Which means that learning design is a systematic and reflective process of translating learning principles and teaching materials, activities, information, resources, and evaluation.

Richey, Klein and Tracey (2011), define "instructional design, the science and art of creating specifications for development, evaluation, and maintenance of situations which facilitate learning and performance" (Richey, Klein \& Tracey, 2011). This means that instructional design is the science and art of making detailed specifications for the development, evaluation, and maintenance of situations that facilitate learning and performance.

Development of learning is a series of rules, or procedures, that are used to make learning according to the objectives of the learning (28). The same is conveyed by Kemp and Smellie (1989), the development of learning is the process of designing a learning program, be it a module, a complete unit, or a course, using systematic and purposeful procedures (Kemp \& Smellie, 1989). This means that the development of learning does not only apply to one course, but also applies to a smaller scale such as a module.

Instructional Design is an important component and is related to other components. Learning instructors, learners, learning materials, learning activities, delivery systems, and learning environments interact and cooperate in an instructional design to

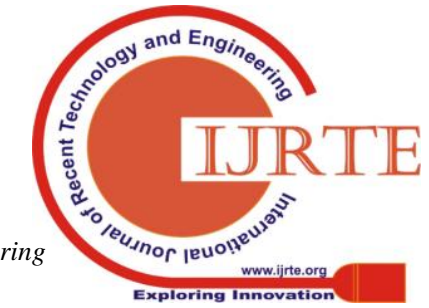


achieve the desired learning goals (Dick, Carey \& Carey, 2009). Understanding of instructional design is very important and needed in order to improve the quality of teaching and training (Reigeluth dan Chellman, 2009). Basically the learning process occurs with or without instructional design, but each learning process will be influenced by things that are external to a learner. Instructional design is made with the aim of making learning more effective, efficient and easier.

Instructional design is more than teaching. The intention of an instructional design is to accommodate and consider all things that can have a direct influence on individual learners. In addition to teaching activities, instruction can be presented in the form of printed material, images, broadcast television, computers and other media. Design and development of an instruction is an essential element of a larger system known as an instructional design system (Reigeluth dan Chellman, 2009).

\section{Learning Materials Hypercontent}

Simonson, Smaldino, Albright, and Zvacek (2005) suggest that ICT-based learning, especially those based on the internet, are basically network-based learning. One of the familiar designations stated by them is a hyper-designed instruction, namely learning that is designed structurally using aapproach hypercontent (Simonson, dkk, 2005).

In a simple hypercontent, it can be understood as a concept that simulates one material and other material simultaneously in a particular digital technology program. The logic is not far from hypertext, ie one text contains many other texts that are connected to each other. The real form is the display menus on thepage website, if clicked it will bring the user (user) to one and the other material. In other words: a text actually holds and connects with other texts (hyper).

Themeaning is hypercontent adopted from digital reading patterns that are nonlinear in nature, namely: (1) othermeanings hypercontent are linked (link) and virtual world (virtual world). (2) non-linear or random patterns, read digitally (Prawiradilaga \& Chaeruman, 2018).

Actually this hyper-designed instruction has a medium character when compared with another approach in the development of learning devices, especially internet-based modules. For example, one of them is theapproach learner-directed design that really puts users not only using learning designs, but also as learning designers, including determining what stages of learning and how to learn. This approach is also called the constructivist learning design model which really positions the user / student as the subject of learning (Simonson, dkk, 2005). Here, thehyper-designed instruction role of the student'sand position have not yet arrived as part of the learning designer. But enough as active users of design and learning devices.

Even so, constructivist nuances and characteristics of cyberspace with random networks still appear. In this case if it is directly related to the module as teaching material, then the parts are clearly designed. Included are presented using multimedia (text, audi, graphics, images, video, audio). But the way of learning does not force students / students to learn in stages in the order that has been designed from the beginning.

Students are free to choose to learn certain parts of material that they consider need to be studied randomly and not sequentially (non-sequential). This method of learning and the use of random and non-sequential modules can be said to be a form of hypercontent (Simonson, dkk, 2005).

\section{METHODOLOGY/MATERIALS}

This research is a development research that will producelearning materials hypercontent to improve the creativity of prospective master guides. In detail the objectives of this study are 1) to describe the learning conditions for prospective master guides so that it is necessary to developlearning materials hypercontent for character education, 2) to obtain data on the feasibility oflearning materials hypercontent for character education, 3) to obtain empirical data about the effectiveness of learning materials hypercontent character education developed.

The research was carried out in the Seventh-day Adventist Church throughout Indonesia. Judging from the purpose, this research can be said as research and development (Research and Development).

Research and Development is used to design new products and procedures, then apply research methods to field trials, evaluate and refine products and procedures to meet the criteria for effectiveness, quality and standardization ( Borg \& Gall, 2007).

The stages of development are as follows:

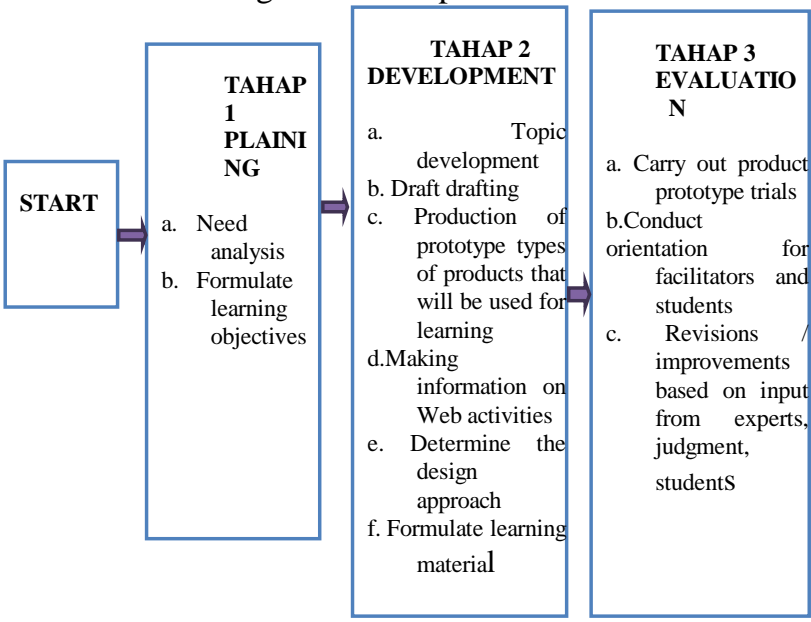

Fig1. Stages of developinglearning materials hypercontent

\section{RESULTS AND FINDINGS}

This research produced a new learning model which was named Jonurro's development model, which stands for Jhoni, Nurdin and Robin. Can be described in the form of the following chart 


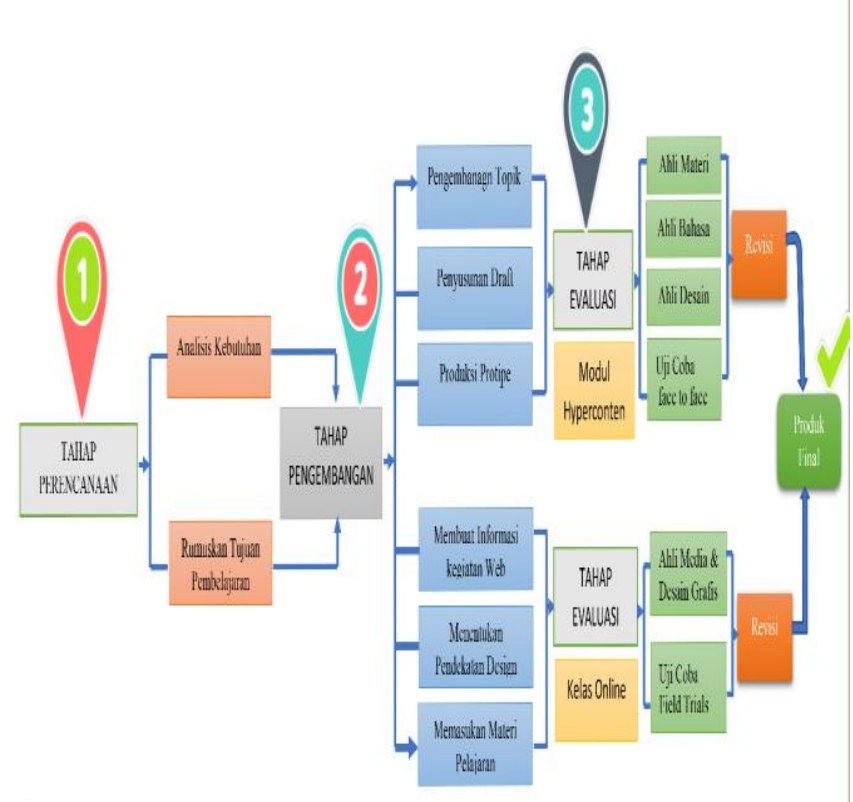

Fig 2. Design of the Jonurro Development Design Model The development

Steps in accordance with the above chart, will be explained below:

\section{A. Planning Stage}

1) Needs Analysis

At the needs analysis stage, carried out by conducting observations to see problems, conditions and characteristics of students. In addition to observation, researchers distributed questionnaires to direct interviewers to instructors and prospective master guide students.

The results of the questionnaire analysis conducted by researchers on 18 members of the master guide provided information that $79.73 \%$ of master guide candidates stated that instructors were planning learning in years, $71,62 \%$ of prospective master guides stated that the instructor did not provide motivation. The $56.76 \%$ of the master guide candidates stated that the use of learning media is not interesting because there are no learning resources such as modules or textbooks. Candidates for the Master Guide are willing to study using the hypercontent module and utilize online learning as a means of communication. While $63.96 \%$ of the master guide candidates stated that the implementation of learning went well enough by giving responses by the instructor to complete the independent task, as well as an explanation of the main points of the material and references by the instructor at each meeting.

\section{2) Formulating Learning Objectives}

After conducting a needs analysis, there are several problem solving learning in the prospective master guide class that are tailored to the characteristics of students, learning problems and the environment.

\section{3) Stage Of Development}

\section{a) Development Of Topics}

Topics developed based on predetermined learning goals are as follows:

1. Spiritual growth

2. Talent development
3. Child development

4. Leadership development

5. Fitness lifestyle development

b) Drafting And Production Product Prototype That Students Will Use To Study.

The drafting is done by pouring the material that has been compiled in an outline of the contents of the module (GBIM) and described in the elaboration of material (JM) into a particular format with the language of delivery and technical terms that have been understood.

\section{c) Prototype Production}

In producing hypercontent learning materials requires equipment in the form of computers, printers, editing programs, layout programs and binding devices. The computer or laptop used has moderate specifications, namely the Lenovo ThinkPad X250 laptop, the software used is Microsoft Office Word 2016, Adobe Photoshop CS6, and video editing programs using the Wondershare Filmora application. To print modules that have been processed, the printer is needed. The printer used is a printer that can print colors with high resolution in this case researchers use Epson printers.

d) Creating Web Activity Information Documents An Event Information Document (WID) Is A Document Designed To Record Basic Information Related To The Learning Material That Will Be Developed.

e) Determine The Design Approach

Determine the tools used to help students complete a variety of activities that have been designed as part of web-based learning material. Among them:

1. Browser software

2. Media player

3. Whiteboard or notepad for student records

4. Access bulletin board

5. Email address

6. Enter all learning

Material Material is prepared using predetermined templates according to the storyboard.

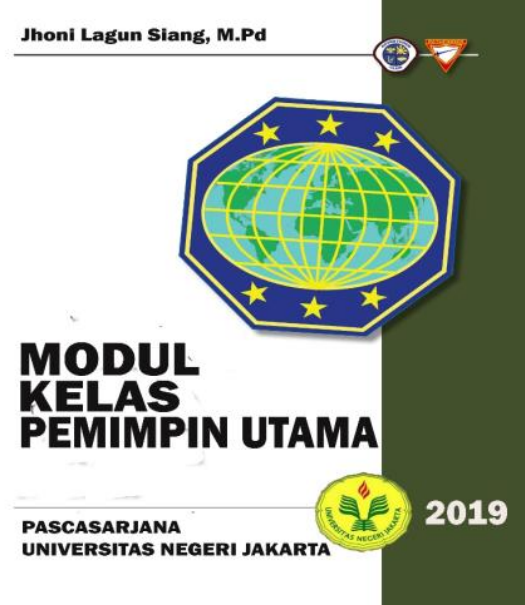

Fig 3. Master Guide Module 


\section{4) Evaluation Stage}

\section{a) Self Evaluation}

Self evaluation is done to see the module's attractiveness. In this stage the researcher conducts a readability test using the Fox Index. The

researcher uses his own fog index to measure the level of readability of discourse or reading material contained in the module. The mathematical formulas are as follows:

Readability level $=0.4(\mathrm{RPK}+\mathrm{KS})$.

Ideal results for readings 7-8.

If the result is:

$>8-12$ is considered difficult

$>12$ is considered very difficult

$<7-3$ is considered easy

$<3$ is considered too easy

The results are as follows:

Table 1. Average value of readability test

\begin{tabular}{lc}
\hline Module or Subject & Level of Readability \\
Spiritual Growth & 6,93 \\
Talent Development & 6,73 \\
Child Development & 7,33 \\
DevelopmentLeadership & 6,38 \\
Fitness lifestyle development & 6,32 \\
Average & $\mathbf{6 , 7 3}$
\end{tabular}

Fig 4. Readability test chart

Based on the results of the calculation of readability from the five subjects, the overall average score was 6.73. This result states that the hypercontent module for prospective master guides in terms of readability is considered easy. This module is suitable for use in learning.

\section{b) Expert Review}

In the expert review stage, products that have been designed are examined, assessed and evaluated by experts. 1). validation is carried out by media experts, material substance experts and languages. At this stage, responses and suggestions from experts (validators) about the design that has been made are written on the validation sheet as material for revising and stating that this design has been valid or not, so that the weaknesses of the product can be made and then revised. An evaluation sheet for design experts and material is attached to this proposal.

The researcher used questionnaires on a 1-4 scale. with the following assessment:

$3.26-4.0$ means very good

$2.51-3.25$ means that either

$1.76-2.50$ means good enough

1.0 - 1.75 means it's not good

After all the data collected is processed using simple statistics. For valuation, use the average of the total values. The average value is used as the basis for providing a level of assessment of the module developed

1. Material Expert The material experts involved were the Adventist Church Guide Master of the DKI
Jakarta Konfrens Church and its surroundings Design

2. experts Media experts involved were lecturers in the Education Technology Study Program at the Jakarta State University Postgraduate Program. Who teaches subjects related to media and learning design.Language

3. experts The media experts involved were lecturers of the Jakarta Postgraduate University language program. Who teaches related subjects.Graphic

4. Graphic Design and Media Production ExpertProduction and Design Media Experts involved are lecturers or experts who teach related subjects.

Modules that have been assessed by experts and have been revised, are ready to be used in the learning process of prospective master guides. The module can enrich the learning resources of prospective master guides. This is in line with the research conducted by Prawiladilaga and Widyaningrum (2017), regarding the basic principles of developing hypercontent-oriented modules. The results of the study show a hypercontent approach to direct module design enriched by learning resources in cyberspace. (Prawiradilaga, Widyaningrum, 2017).

Jou, Chuang and Wu conducted research on Creating Interactive Web-Based Environments To Scaffold Creative Reasoning and Meaningful Learning: From Physics To Products. The results of the study show that: Inquiry modules were able to facilitate investigation and planning activities in product design stages. The responses obtained were very encouraging. Students in the course were appreciative of these on-going changes and indicated that they were indeed helping them to develop their engineering thinking and design skills, increasing their motivation to study. (Jou, Chuang \& Wu, 2010). Print modules can also improve student learning outcomes (Siang, Ibrahim, \& Rusmono, 2017).

\section{c) Face To Face Tryout}

At this stage, the researcher tests the module design that has been developed for students. The selected students are students who have high, medium and lace abilities. At this stage students are asked to give a response or comment on the validation sheet provided for the prototype product. The results of this implementation are used to revise the design that has been made.

After the module is revised, the module is then tested to 3 prospective master guides. From the results of the trial results obtained that the module can be a learning resource for prospective master guides. This is in accordance with the research conducted by Wibowo (2016), the results of the study indicate that: The source of learning by utilization that is used by the teacher in the learning process includes the environment around the school, the environment around where the students live, and learning outside of school. The ability of teachers to take advantage of learning

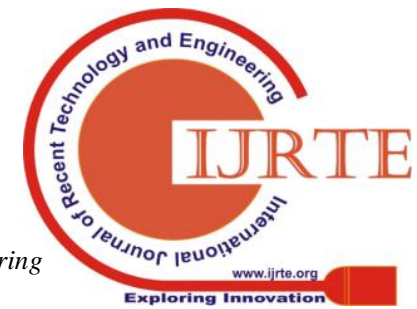


resources by utilization, that is, overall all classroom teachers are able to use it, but still not maximized. The implication of the use of learning resources on the quality of teachers in the learning process is that teachers are more able to provide greater motivation, maximize learning time, and maximize creativity (38). This is in line with research that compares student learning achievement using learning resources and students who do not use learning resources. The study found that there were significant differences between students who had the intensity of the use of high learning resources with students who had the intensity of the use of low learning resources regarding learning achievement (5).

According to the results of research by Amris and Akhyar (2015), about the influence of the use of learning resources on social studies learning achievements, based on the results of research and data analysis, it was concluded that the use of learning resources had an effect on social studies learning achievement of fifth grade students in Bulurejo Elementary School 2015). Abdalraheem and Rabane also found that the use of textbooks in classrooms was still very dominant ( Abdelraheem \& Rabane, 2006).

\section{d) Field Trials}

Suggestions and results of testing on the prototype used as a basis for revising the design of the second prototype. The revised results were tested on research subjects in this case as field trials involving three schools with a total of 20 people taking the field test. The field test aims to find out the shortcomings of the module when it is used in the learning process carried out in class.

After field testing, the module is revised. The results of the module revision are final modules that are ready for use in learning

\section{CONCLUSION}

1. Judging from the readability test conducted by researchers using fog index, the module material is included in thecategory easy.

2. According to the material expert, the hypercontent module, in terms of content feasibility, the feasibility of the feasibility of presentation according to material experts has been very good.

3. According to linguists, the hypercontent module, in terms of the feasibility of language feasibility it has been very good.

4. According to the learning design, the module is hypercontent, in terms of learning design is very good

5. Whereas according to expert media and graphic design, all module components are complete, the module size is appropriate and the visual message design principle is very good.

6. According to the candidate master guide this module, in terms of method, evaluation, module size, language, sentence structure, layout, typography, illustrations and colors in the module have been very good.

\section{ACKNOWLEDGEMENTS}

This research was sponsored by an all-powerful God who gave blessings in the form of health, strength and finance so that this research could work well.

\section{REFERENCES}

[1] Dale H. Schunk. Learning Theories An Education Perspective. Boston Pearson Education, Inc; 2012.

[2] Anurrahman. Belajar dan Pembelajaran. Bandung: Alfabeta; 2010.35 p

[3] Miarso Y. Menyemai Benih Teknologi Pendidikan. Computer. 2007.

[4] Spector MJ. Adventures and advences in instructional design theory and practice . Datam Lestie Moller I Jason Bond Huett I Dougles M Harvey (Eds) Learning and instructional technologies for the $21 \mathrm{ct}$ century; viclone of the future. New Jersey: Springer ScienceBbusiness Media, LLC; 2009. 1-2 p.

[5] Taiwo S. Teachers' perception of the role of media in classroom teching in secondary schools. Turkish online J Educ Technol -Tojet. 2009;8(1).

[6] Fred Percival HE. A Handbook of educational Technology. Kogan Page Ltd, editor. London; 1993.

[7] Barbara B Seels RR. The definition of education technology. Washington DC: AECT; 1994.

[8] Mukminan. Peran teknologi pembelajaran dalam pengembangan dan implementasi kurikulum berbasis kompetensi. Yogyakarta; 2003.

[9] Ahmad Yousef Abdelraheem AHA-R. Utilisation and Bonefits of instructional media and teaching social studies courses as verceived by omani students. Malaysian online J Instr Technol. 2006;2(1).

[10] Dewanto IJ. Pengembangan Model Pembelajaran Rekayasa Perangkat Lunak Berbasis Belajar Pemecahan Masalah. J Teknol Pendidik. 2015;17(3):141-50.

[11] Purwanto PP dan. Media dan Teknologi pembelajaran di perguruan tinggi; berani tampil beda? Yogyakarta; 2003.

[12] Samiawan CR. Pendidikan Tinggi; Peningkatan Kemampuan Manusia Sepanjang Hayat Seoptimal Mungkin. Jakarta: Grasindo; 1999. 25 p.

[13] Gunawardena MSM dan C. Distance education. Dalam David H Jonassen, (Ed) handbook of research for educational communications and technology. New York: AECT; 1996.

[14] Supriadi. Pemanfaatan Sumber Belajar dalam Proses Pembelajaran. Lantanida J UIN Ar-Raniry Banda Aceh. 2015;3(2):2.

[15] Lilawati J. Analisis Pemanfaatan Sumber Belajar Dalam Proses Pembelajaran. In: PembelajaranProsiding Seminar Nasional Tahunan Fakultas Ilmu Sosial Universitas Negeri Medan. Medan: Fakultas Ilmu Sosial Universitas Negeri Medan; 2017. p. 106.

[16] Togi M. Hasil Wawancara dengan instruktur tanggal 17 Februari 2019. Jakarta; 2019

[17] Siregar MS. Hasil Wawancara dengan calon master guide tanggal 17 Februari 2019. Jakarta; 2019.

[18] Alan Januszewski MM. Educational Technology: A Definition with Commentary. New York: Routdege; 2008. 1 p.

[19] Sitepu B.P. Pengembangan Sumber Belajar. Jakarta: Raja Grafindo Persada; 2014. 19 p.

[20] Richey BBS dan RC. Teknologi Pembelajaran: Definisi dan Kawasannya. Jakarta: Unit Penerbitan Universitas Negeri Jakarta; 1994. $13 \mathrm{p}$.

[21] Ibrahim N. Perspektif Pendidikan Terbuka Jarak Jauh. Jakarta: Bumi Aksara; 2010. 136 p.

[22] Sharon E. Smaldino DLLJDS. Instructional Technology \& Media For Learning Teknologi Pembelajaran dan Media untuk Belajar. Penterjemah : Arif Rahman. Kencana, editor. Jakarta; 2012. 302 p.

[23] Yamin M. Desain Pembelajaran Berbasis Tingkat Satuan Pendidikan. Jakarta: GP Press; 2007. p. 115.

[24] Widodo UR\& A. Pengembangan Tutorial Online Yang Mengintegrasikan Panduan Belajar Mandiri Untuk Melatih Self-Regulated Learning. , J Pendidik dan Kebud. 2017;2(2):202.

[25] Hargis J. The Self Regulated Learner Advantage: Learning Scince on the Internet. Electron J Sci Educ. 2000;4(4).

[26] 26. Newby Timothy J. et al. Educational Technology for Teaching and Learning. Canada: Pearson Education; 2011.

[27] Rita C. Richey, James D. Klein and MWT. The Instructional Design Knowledge Base Teori, Researh, and Practice. New York: Routledge; 2011.3 p.

[28] Piskurich GM. Rapid Instructional Design: Learning ID Fast and Right, 3rd Ed. New Jersey: Wiley; 2015. 3-4 p.

[29] Smellie JEK dan DC. Plaining, Producting, And Using Instructional Media 6th Edition.

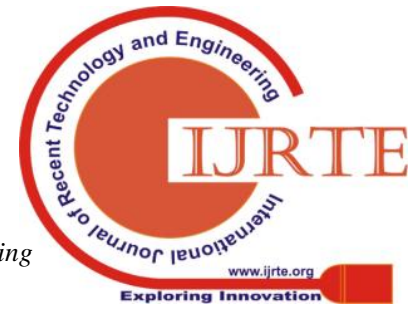


New York: Harper and Row; 1989. 4-5 p.

[30] Walter Dick LC dan JOC. The Systematic Design of Instruction 7ed. Boston: pearson; 2009. 6-7 p.

[31] Charles M. Reigeluth dan Chellman. Instructional Design Theories and Models, Volume III. New York: Routledge; 2009. 6 p.

[32] Simonson, M., Smaldino, S., Albright, M., \& Zvacek S. Teaching at a Distance: Foundations of Distance Education. 3rd Edition. Upper Saddle River, NJ: pearson; 2005. 137-138 p.

[33] Dewi Salma Prawiradilaga UAC. Modul Hypercontent Teknologi Kinerja. Jakarta: Prenadamedia Group; 2018. 2 p.

[34] Meredith D. Borg, Joyce P. Gall WR. Educational Research an Introduction eighth edition. Boston: pearson; 2007. $589 \mathrm{p}$.

[35] Dewi Salma Prawiradilaga, Retno Widyaningrum DA. Indonesian Journal of Curriculum and Educational Technology Studies. Indones J Curric Educ Technol Stud. 2017;5(2):57-65.

[36] Min JOU, Chien-Pen CHUANG Y-SW. Creating Interactive Web-Based Environments To Scaffold Creative Reasoning And Meaningful Learning: From Physics To Products. TOJET Turkish Online J Educ Technol. 2010;9(4).

[37] Siang JL, Nurdin Ibrahim, Rusmono. Pengembangan Paket Modul Cetak Mata Pelajaran Pendidikan Agama Kristen SMP Negeri Tidore Kepulauan. J Teknol Pendidik. 2017;19(3):191-205.

[38] Wibowo EP. Kompetensi Guru Dalam Pemanfaatan Sumber Belajar by Utilized di SDN Catur Tunggal 6. J Prodi Teknol Pendidik UNY. 2016;5(5):36.

\section{AUTHORS AFFILIATION.}

Jhoni Lagun Siang from Post Graduated Department of Educational Technology Universitas Negeri Jakarta, Rawamangun muka street, Rawamangun Pulogadung, East Jakarta 13220, Indonesia, and Lecturer at Universitas Bumi Hijrah Maluku Utara, Sofifi, North Molucas Indonesia, 97852. My area of interest is research and development.

Nurdin Ibrahim, Profesor at Universitas Negeri Jakarta, Rawamangun muka street, Rawamangun Pulogadung, East Jakarta. . My area of interest is research and development

Robinson Situmorang, Lecturer at Universitas Negeri Jakarta, Rawamangun muka street, Rawamangun Pulogadung, East Jakarta. My area of interest is research and development 